\section{Rubbia proposes a speedier voyage to Mars and back}

[MUNICH] The Italian Space Agency has carried out a feasibility study on a new type of propulsion engine that would allow interplanetary travel at speeds fast enough to make manned trips to Mars a realistic proposition. The agency is planning to investigate the idea further, says its science director, Giovanni Bignami.

The idea was developed by Italian Nobel prize winner Carlo Rubbia, the former director of the European Laboratory for Particle Physics (CERN) in Geneva, now professor of physics at the University of Pavia, near Milan. His proposed engine uses fission fragments of the element americium to heat a propulsion gas directly.

An interplanetary propulsion system called NERVA is being studied by the US space agency NASA. NERVA is based on a classical nuclear reactor, using solid fuel rods to transfer energy to a propulsion gas. The amount of energy generated is therefore limited by the melting point of the fuel rods.

In contrast, Rubbia's engine has the fuel, an isotope of americium, painted thinly on the inside wall of a chamber containing hydrogen gas. The chamber is surrounded by graphite, which acts as a reflector for neutrons bombarding the americium fuel. Neutrons would be provided both by a natural source and by the americium fission process itself.

Reflected to and fro across the chamber, the neutrons pass frequently through the americium, and have a high probability of colliding with americium atoms. The fission products of such collisions scatter into the chamber and deposit their energy in the gas.

According to Rubbia's predictions, the gas could be heated in this way to up to $14,000 \mathrm{~K}$, and could be used to generate speeds of up to 40 kilometres per second. A manned trip to Mars and back could be achieved in around a year using such a propulsion system. In contrast, a trip using NERVA is calculated to take four years.

"Survival of humans in space is intrinsically limited by cosmic radiation, even on the surface of Mars with its thin atmosphere and weak magnetic fields," says Bignami. "So cutting mission duration by several years in itself makes the difference between a dream and a feasible mission."

Rubbia stresses that the concept is "just an idea" but is "based on easy scientific principles and the development of a machine which would theoretically be very reliable because it would have few moving parts". The Italian agency is now planning a design phase involving industry and international partners, says Bignami.

Alison Abbott

\title{
AAAS head wants to see scientists on school boards
}

[ANAHEIM, CALIFORNIA] US scientists were urged last week to actively promote science education by M. R. C. Greenwood, chancellor of the University of California at Santa Cruz and president of the American Association for the Advancement of Science (AAAS).

Speaking at the association's annual meeting, Greenwood said scientists should re-examine their responsibility for meeting the needs of society. She called for the AAAS to launch a campaign to ensure there is at least one scientist, engineer or scientifically literate person on every school board.

Greenwood argued that the falling academic performance of US schoolchildren threatened not only the next generation of scientists, but the whole national support system for science. She pointed out that a 1995 study found that US 12th graders scored nearly bottom of 50 nations tested in science skills, and that even advanced placement students in subjects such as physics ranked extremely low.

Greenwood placed the blame for this on poor textbooks, on teachers with little experience of studying science, on a lack of attention to women and minorities, and on a vocal minority of parents and community leaders who are hostile to science education. These factors have allowed an aversion to science to

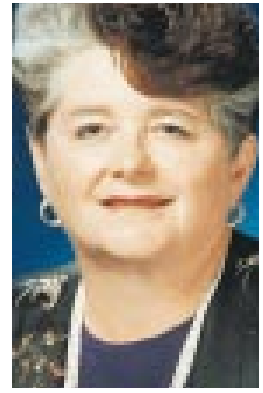

Greenwood: plans to tackle school science. seep into the classroom, said Greenwood.

She urged scientists to take a lead from grassroots groups who target school boards to further their political agendas. Religious fundamentalists, for example, have used membership of school boards to prohibit the teaching of evolution or to require announcements that evolution is merely a theory.

Although the AAAS would not run political campaigns itself, she said it should encourage scientists to take public office. Such scientist-activists would seek to convince school boards that science, engineering and mathematics are critical life-skills for all students. The AAAS would provide materials and a network of experts to support members' efforts to improve pedagogy, curricula, textbooks and student assessment.

Greenwood, who presented the plan to AAAS membership at the meeting, plans to develop a proposal for the board and seek funding for a workshop on her proposed strategy by the middle of 1999. Sally Lehrman

\section{Harvard reveals plans for research centres}

[вољтоN] Harvard University announced last week that it will invest between $\$ 150$ million and $\$ 200$ million over the next five years in new programmes in science, with a special emphasis on interdisciplinary activities.

A panel of faculty members, set up last summer to identify the most promising research directions, has recommended the establishment of several new research centres. Two of these - the Center for Genomics and Proteomics and the Center for Imaging and Mesoscale Structures have already been approved for funding.

Three more centres are being considered: a neuroscience facility to explore the connections between single nerve cells and an organism's behaviour by studying large groups of neurons simultaneously; a content engineering facility to develop Web search engines to mine scientific databases; and a programme to examine links between global climate change and biological evolution.

The new programmes, says chemist Jeremy Knowles, dean of the university's arts and sciences faculty, will cross departmental boundaries and foster research and education along interdisciplinary lines.
“The old paradigm of a single investigator applying for grants and then assembling a lab and a research group has become less viable in a number of fields," he adds.

Investigators at the genomics centre will study genes and their proteins, exploring animal behaviour, evolution, the genetic causes of disease and other complex biological phenomena. Those at the imaging centre will mainly study extremely small structures on the scale of 1 to 100 nanometres, with applications including the design of smaller computer processing and fibre-optic communication systems, the creation of biomaterials and drugs, and the development of optical and scanning technologies for medical diagnostics.

Harvard is eager to get the first two centres operating, says Knowles. Although some construction is planned, they will initially use existing facilities, he says.

About $\$ 70$ million dollars has been allocated for equipment, staff and construction projects. Knowles says other centres may be created as Harvard strives to pursue "the most exciting and fruitful areas of inquiry".

Steve Nadis 